\title{
Trade union politics as a countermovement? A Polaniyan perspective
}

\author{
Martin Seeliger (martin.seeliger@uni-flensburg.de) \\ Europa-Universität Flensburg, Germany
}

The article develops a conceptual proposal for the inquiry of trade unions. On the basis of Karl Polanyis theory, four patterns of political mobilization applied by trade unions in the current Transformation are pointed out.

Keywords: Polanyi, Trade Unions, Countermovement, Internationalism

\section{Introduction}

Cross-border interdependencies between far-away places induced through transportation and communication technologies have been enigmatically summed up under the term of globalization, the main consequences of which are taking place in the field of the economy. Under capitalism (i.e. an overall economic system characterized by market-coordination and relative concentration of capital in the hands of only a few), the labor market constitutes the co re piece of the economy. This fact is also reflected in the central position of dependent wage-labor in classical sociology.

In modern capitalist societies, the process of negotiating a price and a (relative precise) return service of work to be done, is (usually) set within the triangle of three actor groups; namely labor, capital and the state. In order to conduct their political representative work, labor (and to some degree also capital) constitute interest organizations. From a social science perspective, analysis of trade union politics can be seen as an endeavor for middlerange theories (Merton 1968) from an organization studies' perspective (Child et al., 1973). Under conditions of economic globalization (and also European integration, which in the following, we would like to understand as a special case of globalization) trade unions are increasingly exposed to a de-territorialization of their political reference frame. As one of the central institutional pillars of capitalist economies is the exploitation of dependent workers in the labor market, these developments are causing transformations in the everyday life of working people on a global scale (Walby, 2009). The question over how trade unions represent workers interests under conditions of economic globalization is, thus, not a goal in itself - at the intersection of macrosociology and political economy (Streeck, 2015, 8 ), it is an essential part of a broader research agenda aiming at the conflictual relationship between capitalism and democracy (Nachtwey, 2016).

In order to apply the middle-range theory perspective of trade union research to such a research agenda, I will in the following be drawing on Karl Polanyi's main book 'The Great Transformation'. With inquiry of the historical pendulum dynamics between market-disembedding and societal counterforces, Polanyi has created a powerful heuristic, which I can use to understand current dynamics in the relationship between economy and society. From this perspective, trade unions do not constitute the ultimate reference point, but 
appear as a group of actors within a greater continuum. By drawing on Polanyi, I assume that under conditions of globalization and European integration at the beginning of the $21^{\text {st }}$ century find ourselves in the middle of another Great Transformation in the Polanyian understanding.

After introducing a theoretical framework to understand trade union action under conditions of globalization and European integration (2), the fundamentals of Polanyi's Great Transformation will be sketched out (3). Those insights will then be applied to the object of trade union politics (4). A final conclusion will interpret those considerations against the background of the broader discussion about the role of trade unions within the institutional nexus between capitalism and democracy.

\section{What are trade unions and what do they do? A sociological perspective}

What exactly are trade unions? According to a traditional definition provided by Sidney and Beatrice Webb $(1895,1)$, a trade union can be understood as the "continuous association of wage earners for the purpose of maintaining or improving the conditions of their working lives". As co-founders of the London School of Economics and protagonists of the socialist 'Fabian Society', they personified a type of scholarship that has left its mark on the sociological study of trade unionism up until today - the dedicated observer. If we look back into the history of academic scholarship, we find - except for a few examples - a general sympathy for trade union concerns. But what exactly are these concerns?

As associations aiming "to fight the threats of capital", Engels (MEW 19, 258) understands trade unions from a perspective of what became known as sociology of conflicts. In order to represent the interests of the wage earners, their task lies in exercising political pressure to maintain and increase labors' share in societal wealth. "Only the fear of the trade unions", Engels (MEW 19, 253) concludes, "can force capital to pay the workers the entire value of their labor power". While this role of trade unions as "cartels of sellers of labor" (Streeck, 2005, 263) is therefore limited to the fields of wage-setting as well as labor and employment standards, political activities of trade unions are secondly extending into other fields. A broader understanding of trade unions as "interest associations of workers in waged employment" (Streeck, 2015b) leads us to their (more general) role as actors within the political system. As the historical examples of the Spanish Confederación Sindical de Comisiones Obreras against Franquism or the Polish Solidarność under Perestroika show, trade unions are setting the political stage also beyond those fields of immediate collective bargaining. Thirdly, trade unions can - as in the so-called Ghent System of Unemployment Insurance (Clasen \& Viebrock 2006) - constitute internal communities of solidarity. Such "cooperative functions" rest, according to Franz Neumann $(1978,150)$, "on the fundaments of mutual help". Fourthly, and here we are not coincidentally entering the field of culture, trade unions play a role for socialization and education of their members. As "schools of war" (MEW 2, 436), trade unions are not only shaping their political conscience. By providing their members with a sense of belonging (also through entertainment and leisure activities), trade unions can contribute to an overall class identity. Whether in the "proletarian general strike" with its "only task of destroying state power" (Benjamin, 1999, 51) or through organizing a local day care initiative - "the foundation of trade unionism involves building a practice of collectivity" (Fairbrother, 2014, 638).

As John Child et al. (1973) have noted in their groundbreaking text, the question on the primary tasks of trade unions has - on an empirical, as well as a political level - called for significant discussion:

"Much of this has centered on the question of whether unions do or should function primarily to perform an economic service for their members, or function primarily as agents for social change and as the institutional means for their members to participate more fully in democratic processes" (ibid., 71). 
Facing the interdependent processes of European integration and globalization, again inspired by Franz Neumann $(1978,151)$, I want to address trade unions under two aspects: As "fighting associations", trade unions are aiming for "dominance over the labor market", serving as cartels of wage-earners to challenge the monopolistic power of private capital. A first focus therefore shall be set on wage-policy. Central motives of wage-setting are stemming from the internationalization of the labor market through parallel production (Altvater \& Mahnkopf, 1993) and mobility (Wagner \& Lillie, 2014), as well as the austerity politics implied in European integration (Schulten \& Müller, 2013). A second focus shall moreover be set on trade unions' ambitions to influence the state. Current framework conditions of trade unions' attempts to lobby government are - due to the course of European integration - directed at EU institutions.

By influencing the distribution of societal wealth through collective bargaining as well as labor market and social policy, they contribute to regulating the distributional conflict at the center of capitalist societies (Krämer, 2015). By understating trade unions as protagonists of economic democracy (Brinkmann \& Nachtwey, 2017, 7), I therefore refer to the field of collective bargaining (e.g. through minimum wage or pension schemes) and to their impact on agenda- and rule-setting within the political system.

\subsection{Trade union politics under conditions of globalization and economic integration}

The evolution of transport and communication technologies, liberalization of world trade under the Washington Consensus and the growth of population in the urban areas of newly industrialized countries, have over the last years led to a development which social scientists have summed up under the term 'globalization'. It is easily noticeable that a central commonality of these trajectories stems from their economic dimension. With no polemics involved, it can therefore be stated that globalization has, so far, primarily taken place as a globalization of markets.

Impressively far-sighted, Marx and Engels anticipated these developments in their 'Communist Manifesto' in the middle of the $19^{\text {th }}$ century as a central characteristic of the capitalist order. "The need of a constantly expanding market for its products" they (MEW 3, 465) state, "chases the bourgeoisie over the whole surface of the globe." In search for profit opportunities, the chance to move production facilities overseas does not only grant access to foreign consumer markets, but also increases potential supply of resources and labor power.

From a trade union point of view, consequences for the collective bargaining mandate arise. In order to function as an effective cartel in wage-setting, a trade union has to organize as many workers in a segment of the labor market as possible. In the context sketched out here, two problems arise: Firstly, companies can relocate services and production. In practice, such threats are not only directed at unions, but also in negotiations with local, regional or national government. Instead of collective bargaining agreements, such attempts are normally directed at tax reduction or lowering of social standards. ${ }^{1}$

In a globalized world, mobility is a property not limited to capital. In the 'Age of Migration' (Castles et al., 1993) migrant labor constitutes an integral part of economic development. Traditionally leaning towards the political left, trade unions are therefore often facing a political dilemma. While universally promoting human rights would require representing the interests of all wage earners (and thus also those of the migrant workers), organizing all workers can easily exceed trade unions' organizational and political capabilities. Accordingly, through hiring migrants (or supporting liberal immigration policies), capital has historically attempted to increase pressure on wages (be it through employing irregular migrants, subcontracting foreign companies, or simply threatening to do so).

\footnotetext{
${ }^{1}$ If capital manages to establish a credible threat, these measures do not even require an actual capacity to relocate.
} 
The problems trade unions are facing under globalization therefore center around organizing the workers in an expanding market for labor. While product markets and values chains are increasingly exceeding national territories, national borders at the same time limit the space within which trade unions can successfully organize their particular workforce.

In the research literature, possible consequences of this development have - somewhat schematically - been discussed under the heading of the 'race-to-the-bottom' hypothesis (vgl. Fuchs \& Offe, 2009, 425). According to this assumption, competition between workers, trade unions (and ultimately also states undercutting each other in terms of tax and social policy) is ultimately causing a systematic downgrading of social standards. While mobile capital can engage in global 'regime shopping' in order to play out national unions and governments against each other to find the most attractive investment opportunities, the later ones are even further weakened through the influx of mobile workers. Regime competition and labor migration can therefore be regarded as the two central challenges for trade union politics under conditions of globalization.

If we understand globalization as a general increase of interdependence between events in distant places, European integration can be regarded as a special case in so far as these interdependences are structured through a supranational political system. Through creating a common market on the basis of the four freedoms (free movement of goods, capital, service and labor) and the common currency, European integration has over the last years been qualitatively deepened (Höpner \& Schäfer, 2008). From a trade union perspective, the loss of barriers for cross-border services is a particularly delicate problem (Bücker \& Warneck, 2010). While international economic relations are made much easier to establish, EU-wide norms designed to maintain national minimum standards have so far not been created. Two additional problems are created through European monetary union, firstly by disabling the option of devaluating national currencies (Matthijs \& Blyth, 2015) and macroeconomic adjustment through austerity politics (Schulten \& Müller, 2013; Stützle, 2014).

At the same time, European enlargement has, since the beginning of the $21^{\text {st }}$ century, increased the heterogeneity between the national settings among the Member States (Höpner \& Schäfer, 2012). Especially through the accession rounds of 2004 (Estonia, Latvia, Lithuania, Slovenia, Poland, Czech Republic, Hungary, Slovakia, Cyprus, Malta) and 2007 (Bulgaria and Romania). Facing the diversity between the EU 28s varieties of capitalism, the task to develop a common political line appears to be a particularly difficult endeavor for European trade unions.

\subsection{Trade union research as macrosociology}

In order to understand societal change at the beginning of the 21st century, capitalism constitutes the most comprehensive reference frame to understand human action. A macro-sociological perspective, in the sense of the classics of the discipline ${ }^{2}$, has therefore be informed by elements of political economy. In this context, the political sociology of trade unions played an important role for the evolution of the discipline as a whole. In their study of the 'International Typographical Union' in US of the 1950s Seymour Martin Lipset, Martin Trow and James S. Coleman (1956) have addressed the question of political representation in modern societies as a core problem of democratic mobilization. Another classic in this sense is the study on 'Citizenship and Social Class' by British sociologist Thomas Humphrey Marshall, who assigns a key role to trade unions for the evolution of modern citizenship. Also, for the Global South, Eddie Webster (1985) shows the impact of organized labor in overcoming (post-)colonial dominance.

${ }^{2}$ According to Giddens (1971) these are Marx, Durkheim and Weber. 
Against this background, Wolfgang Streeck $(2005,257)$ formulates the programmatic orientation of sociological trade union research as follows:

"Largely disregarding unions as economic actors in a strict sense, sociologists considered them primarily in the context of work on social mobilization and political organization, or collective action in general, as well as on modernization, nation building, the political-institutional representation of societal cleavage structures in twentieth-century democracies, and the institutionalization and pacification of the class conflict in industrial societies."

As has been highlighted in the study of corporatism (Streeck \& Schmitter, 1999), the stabilizing role of trade unions in the industrialized countries has emerged in the second half of the $20^{\text {th }}$ century under conditions of low unemployment, strong social democracy and comparatively low competition in the world market. Nowadays, however, internationalization of value chains and labor markets has put this constellation into question. If stagnating wage developments can no longer be compensated for through low-priced imports from China or cheap credits from the financial markets, the political challenge for the left becomes the fight against public austerity.

Especially in the European Union, coping with the dogma of austerity (Blyth, 2013) has to be considered a part of the trade unions core business. Therefore, "a self-understanding of trade unions as an offensive counterforce" (Goes, 2016, 93) or the role of a "troublemaker" (Urban, 2013) would have to be reconnected to the assumption that "the mission of trade unions is always following a political motive" (Neumann, 1978, 164). Against this background, the question arises; how to politicize trade unionism in the course of market globalization and public austerity?

As a basic reference point of trade union internationalism traditionally, according to Bormann and Jungehülsing $(2015,57)$, it serves the principle of a "worldwide inclusion". This principle, the authors (ibid., 58) go on to explain, is resting on the following idea: "The interests of those exploited by capital are generally the same on a global scale and the indignation about the injustice should therefore be equally global". In fact, however, empirical reality does not always fit this conceptual assumption. Although global inequalities have long shaped the organization of work and thus the distribution of wealth, we can from this - not derive a homogenous set of interests amongst the global working class. ${ }^{3}$ While aiming to organize all workers in an internationalizing labor market, an important landmark for trade unions has long been reached through the establishment of international associations. If, however, we assume that in order to prevent cross-border competition a global (or at least: international) arena for collective bargaining would be necessary, urgent need for development becomes apparent. The challenges arising from this for the trade unions, we will now to reflect with reference to the work of Karl Polanyi.

\section{Karl Polanyi's The Great Transformation as a macrosociological framework?}

\subsection{Karl Polanyi as a macrosociologist}

"Some books refuse to go away. They get shot out of the water by critics but surface again and remain afloat". In his review of The Great Transformation, Charles Kindlberger (1974, 45) anticipated the impact of the book over four decades ago: The insights about the destructive character of capitalist markets which Polanyi gained under the impression of World War Two can be transferred to contemporary developments of economic globalization (Block \& Somers, 2014). At the intersection of anthropology, economic history and

${ }^{3}$ Essentially, is seems at least questionable, in how far such a general homogeneity of interests can even be assumed for smaller reference units, such as the nation state. 
political economy, Polanyi works on the traditional (i.e. in this context mainly Weberian and Durkheimian) question of the social embeddedness of capitalist markets.

Based on his critique of an "economic fallacy" in liberal economic theory, Polanyi shows how the production and distribution of goods is not only organized through the market, but under more complex institutional conditions. Accordingly, capitalist modernization is evolving as an interplay of the market as the dominant institution (disembedding) and a subsequent complementation through the impact of other social institutions (reembedding). As drivers of this development, Polanyi identifies the social constitution and transformation of three objects, which he calls fictitious commodities; labor, land and money. All of these three 'fictious commodities', so he argues, are not originally produced to be sold in markets. Instead they are gaining their particular character as commodities by political design. The fact that people work to make a living is a constant throughout human history. Furthermore, Rosa $(2016,394)$ describes work as a "a primary form of human relations with the world", and therefore "a foundational reason for sociality and sociability". If, however, men start treating labor as a commodity to be bought and sold in markets, they endanger its use-value. Through increasing commodification of the three fictitious commodities, a society is increasingly undermining the fundament of its own sociality.

For this reason, the commodification of the fictitious commodities has historically caused the emergence of counterforces. From his holistic perspective on economy and society, the capitalist social order appears as a genuinely precarious result of social and political struggles. Since the 19th century, two waves of market disembedding have been complemented through the establishment of social protection mechanisms (i.e. de-commodification). The political subjects behind these developments Polanyi identifies as countermovements.

The reform of the poor laws, which terminated the coupling of minimum incomes to the price of bread, as well as the privatization of rural areas, drove the English workers from the end of the $18^{\text {th }}$ century into the cities. Through political pressure exercised by the in dustrialized working class (and especially through the economic crisis of the 1870s), laws for the regulation of the labor market emerged. Here, the countermovement originally emerged from the regional context of working people's everyday experience (Kocka, 2015).

A second wave of disembedding started after the dissolution of the gold standard. After World War I, the economic consequences of volatile exchange rates increased the pressure on the working class. As political reaction to this commodification of money, the second wage of re-embedding emerges from the national level. According to Polanyi, the results of this countermovement manifest in Roosevelt's New Deal, but also in the form of Stalinism and German Fascism. Evidence for an international countermovement, however, can later be found in the Bretton Woods institutions. From the fatal consequences of World War II, as a consequence of liberal economic doctrine, Polanyi finally drew the conclusion that those destructive forces of society could never be mobilized again.

However, his prediction turned out wrong. Initiated through the oil crisis in the 1970s, (re) and fostered through the internationalization of economic relations since then, commodification of labor, land (nature) and money on an international scale had risen to a new maximum. In the labor market, this constellation translates into multiple patterns of downward competition, that set individuals, companies and even regions or countries into economic rivalry. In this context, over the last decades trade unions have been further weakened through the general liberalization of industrial relations institutions (Baccaro \& Howell, 2017), in particular in Latin America and the EU through politics of austerity (Schulten \& Müller, 2013). 
As Polanyi's perspective on the gold standard reveals, he does consider the international spatial dimension of market embeddedness (Block \& Somers, 2014, 61). In the middle of the 20th century, he was, however, unable to properly anticipate the effects of globalization on the institutional transformation of economy and society. Subsequent to the countermovements of the 1930s, numerous authors identified a new wave of disembedding on a global scale (e.g. Seccareccia, 2012; Burawoy, 2010). The next section reconstructs Polanyi's theoretical implications from a sociological perspective

\subsection{The Great Transformation - theoretical presmises and consequences}

In order to understand the theoretical premises, and thus open up the potentials of Polanyi's theory for (macro-)sociological analysis, this section provides a short historical attribution (for a comprehensive analysis, see Dale, 2017). His most important intellectual imprint, Polanyi received in the political environment of 'Red Vienna' in the 1920s. The idea of a just society on the basis of the principles of democratic political design and egalitarian distribution of wealth guided the works of Polanyi already at this early point in time. Consequently, the historical analyses in The Great Transformation were directed at the tensions and ruptures that the rise of European fascism had caused across and beyond Europe. ${ }^{4}$

The reception of Polanyi had within the first two decades after his death, had been mainly limited to the disciplines of anthropology and history. However, beyond this his ideas gained - not least under the impression of liberal politics induced by Margot Thatcher and Ronald Reagan - more popularity in the broader field of social science (Dale, 2015) and thus gradually turned into a strong theoretical reference point for (critical) sociology of capitalism. In order to make Polanyi's ideas accessible for the (macro-)sociological analysis of trade unions in the interplay of economy and society in the process of European integration and globalization, a number of premises and conclusions shall be spelled out in the following.

In his reconstruction of societal development as a pendulum movement between the disembedding and reembedding of the market, Polanyi chooses an approach, which - in contemporary vocabulary - could be referred to as 'Historical Institutionalism' (see Skocpol, 1979). To Polanyi, the particular role of markets for societal transformation appears as fundamentally ambivalent. While, to him, the market on one hand constitutes a central coordination mechanism for the production and distribution of goods, Polanyi - at all times - highlights its destructive potentials. The idea of the market being embedded into society for Polanyi serves as an instrument to criticize the ideological fiction of (neo-)liberal thinking, which normatively promotes the 'free market' to the central societal institution. In social praxis, Polanyi proclaims, such ideology serves as a political instrument in the sense of a 'hegemonic project' (Wissel, 2015), aimed to weaken the state as a regulatory instance.

With the concepts of 'economic fallacy' (Marx), 'fictitious commodities' (Tönnies) and 'embeddednes' (Thurnwald), Polanyi makes explicit reference to the historical fundus of macrosociology. His analysis of the cultural preconditions of market-based economies can, moreover, be traced back to the notion of non-contractual preconditions of the contract, as well as Weber's focus on the Protestant Ethics as a historical precondition of the capitalist economy. Especially his focus on the liberal ideology of free markets here constitutes a parallel to Weber's emphasis of ideas as drivers of institutional change. Through this particular focus, Polanyi fundamentally differs from Marx, with whom he is mainly connected through their mutual interest in establishing an evolutionary model of societal

4 Remarkably, the publication date of ,The Great Transformation' falls together with Friedrich August von Hayek's (1994) ,The Road to Serfdom', which complements the contemporary critique of totalitarian socialization from a liberal perspective. 
transformation. While Marx, under capitalist conditions, preassumes a particular commodity form, Polanyi illustrates how labor (as well as money and nature) are taking on this particular form. For us, the important innovation of Polanyi - as compared to his theoretical successors - becomes apparent in his discussion of those political forces, mobilizing against market-based societal coordination.

If, in line with Polanyi, we interpret neoliberal globalization as a movement of disembedding, attention needs to be drawn to the possibility of a countermovement emerging. An optimistic perspective can in this regard be found in the field of Global Labor Studies (Webster et al., 2009). Through increasing international competition as well as under conditions of austerity and liberalization, pressure on the international working class has, according to Silver $(2005,36)$ for example, led to a new swing of the pendulum to be expected. A similar continuity is realized by Nobel Prize winner Joseph Stiglitz in his Preface to The Great Transformation: Polanyi's Arguments, he (2001, VII) explains "are consonant with the issues raised by the rioters and marchers who took to the streets in Seattle and Prague in 1999 and 2000 to oppose the international financial institutions". Finally, a similar conclusion is also drawn by Jürgen Habermas $(2000,85)$ : "If a 'double movement' - the deregulation of world trade in the nineteenth century, and its reregulation in the twentieth can serve as a model, then we may once again be standing at the brink of a 'great transformation'"'.

Regarding the actual the emergence of such a countermovement, a number of doubts and objections can be found in the research literature. In this sense, Fraser (2013) detects a fragmented workforce, a lack of leadership, and a decreasing importance of the national arena. A functionalist and teleologic interpretation of Polayni is also criticized by Burawoy (2010, 307), who notes that complex historical sequences cannot be reduced to cyclical mechanisms. The fact that in globalized markets wage earners from distant world regions are set into competition with each other, does not automatically call for a global countermovement.

When trying to apply Polanyi's theory, the perspective of Global Labor Studies, through its designated focus on international phenomena, bears two central problems. Firstly, these are rooted in the fact that Polanyi presumes the territorial framework of the nation state as the unit of analysis to inquire countermovements. ${ }^{5}$ Yet also empirically speaking, constellations of labor regulation are mainly bound to the national level. "Presently" (Streeck 2016), we can observe 'bottom-up'-attempts of recommissioning democratic institutions to the service of a countermovement against accelerated capitalist modernization" (own translation). Regarding the nexus of trade union politics, this argument shall be taken up further below.

\subsection{Applying Polanyi - on the operationalization of the theory}

Against the background of socioeconomic effects of neoliberal globalization and informed by the ideas of Karl Polanyi, I attempt to understand trade unions' capacities of political mobilization. The political sociology of trade unions is usually applying a micro- or mesotheoretical focus on what is going on in and between organizations. I am using Polanyi's concept of the countermovement as a theoretical instrument to connect meso-level mobilization to the macro-sociological questions of conflicts over globalization and European integration.

While Karl Polanyi has been taking on a retrospective view on long-term developments within the relationship of economy and society, what is missing in his arguments is an

\footnotetext{
5 "The parameters of the double movement's protective project were therefore clear: in order to manage its national economy, the state needed to mobilize the national purse, which in turn required controlling the national currency" (Fraser, 2013, 125).
} 
explicit theory of class mobilization. ${ }^{6}$ This blank space we would like to fill through setting our focus firstly on the present, and secondly on political action between trade union organizations.

Political action to represent workers interests is mainly taking place in the field of collective bargaining (towards capital) and in the field of lobbying (towards the state). The counterpart on the company level is the particular management. In order to gain political action capacity, workers have to coordinate their particular positions or, as Marx (MEW 23, 319) states in Capital "put their heads together" [own translation]. This process of coordinating particular interests into a more general 'class interest' we will in the following refer to as 'mobilization horizon', consisting of a spatial dimension and a practical dimension.

For the representation of workers interests, the nation state constitutes only one reference frame out of many. For the aggregation of workers' interests, the question of international solidarity does not arise generally, but only with regards on the effectiveness of various political coalitions. While trade unions have over the last decades managed to establish well-working structures of coordination and representation on an international level, we can - in line with Polanyi - also expect a re-nationalization of political mobilization.

The practical dimension of the mobilization horizon shall in the following be analyzed based on Donatella della Porta's model of political participation in social movements. In her conception, della Porta portrays a tension between the principles of deliberation and representativity: "Participation and deliberation", she $(2015,165)$ explains "are in fact democratic qualities in tension with those of representation and majority decisions and alongside these in a precarious equilibrium in the different conceptions and specific institutional practices of democracy." As preconditions of deliberative mobilization, she (ibid., 166) identifies the following elements: an interactive practice of preference formation, orientation to the public good, rational argumentations, consensus, equality, inclusiveness and transparency. Political mobilization can therefore vary with regards to its spatial reference frame and its micropolitical dynamics. These considerations shall be applied in the following to four ideal typical patterns of trade union mobilization as a reaction to the global disembedding of the labor market.

\section{Trade unions in the Great Transformation - patterns of political mobilization}

Based on Polanyi's ideas in the following we will distinguish four mobilization horizons with regard to their spatial and practical dimensions.

\subsection{Elitarian internationalism}

If globalization of the labor market from a trade union perspective primarily means an increase of labor supply for the capital-side, the most obvious strategy for the unions could be the extension of the cartel of wage earners in a similar scope. Together with their lobbying towards international institutions (such as the EU or the United Nations) such activities constitute the core agenda of trade union internationalism in the $21^{\text {st }}$ century (Pries, 2010). At the same time, when trying to craft common political positions on a cross-border scale, two important challenges make this endeavor a difficult task for trade union organizations: the economic heterogeneity of the different countries involved, and the weakness of vertical decision-making structures within the political multi-level system. While national (or regional, sectoral or even company- or plant-specific) differences can cause

\footnotetext{
${ }^{6}$ It can be assumed that this shortcoming derives mainly from the scholarly context of his time, The Great Transformation appeared 1944 almost two decades before the first publication of 'The Making of the English Working Class', in which E.P. Thompson (1987) primarily reconstructed how political subjectivity emerges from workers everyday routines. With their case study-based focus on trade union action and mobilization capacity, Global Labor Studies are beginning their work on the level below.
} 
diverse interests among different factions of workers, lacking capacity to take decisions makes representation of shared class interests often difficult.

At the same time, an internationalist orientation constitutes a leading value of the labor movement under moral ("All men become brothers!"), as well as under functional ("They have a world to win!") aspects. As 'natural systems' (Scott \& Davis, 2006) trade unions are permanently maneuvering between the interests of different status groups (be it representatives of different secretariats, the chairperson, the members, particular regional representatives). Here, the everyday practices of trade unions' representative work are regularly showing a tendency, which I would like to capture with the concept of an 'elitarianinternationalist mobilization horizon'.

The systematic decoupling of delegates' goals from the interests of the political basis constitutes a well-known motive within the internal dynamics of interest organizations, which has already been portrayed by Robert Michels (1911) as the 'Iron Law of Oligarchy'. Especially with regards their position towards European integration, such tendencies have repeatedly been found among international trade union representatives. As Hyman (2013) or Wagner (2013) claim, a particular mindset is emerging among ETUC-representatives, whose strong identification with the project of European integration translates into general support of the European Commission. ${ }^{7}$ This mindset, according to which problems of European integration can solely be solved through more measures of European integration, Höpner (2015) describes as "integrationism". While prominent especially among international secretaries of trade unions, it can generally be found among all kinds of political representatives and supporters in academia.

As an example, the problematic consequences of integrationist reasoning can serve a proposal of Loh and Skupien (2016), who claim that "a strong transnational trade union movement and a European unemployment insurance scheme could level the negative effects of forced economic integration." In the course of turbulent economic dynamics within European Monetary Union, such a scheme can, in regions suffering an economic crisis, where social security systems are encountering increasing pressure, "enable secret transfer payment within the Union" (ibid., 599).

What may appear as desirable when considering the social discrepancies between the Member States, reveals its practical meaning only against the background of its actual consequences. By extending the group of those entitled to insurance payouts, additional distributional conflicts could arise between the national populations of the Member States. To implement such schemes "secretly" (as the authors like to put it), clearly illustrates the motif of decoupling the political interests of a few above the heads of those who are mainly affected. Political initiatives for international redistribution, which are unable to organize parliamentary majorities - as e.g. the recent austerity measures indicate - are not causing transnational solidarity but an authoritarian shift to the political right.

\subsection{National-authoritarian mobilization horizon}

In any case, a countermovement against the globalization of the labor market is currently emerging not on an international scale, but - in line with the classical Polanyian argument - from the national level. The success of the mobilization horizon which I would like to term as 'national-autoritarian' is traced - from a materialistic point of view - back to the fact that "a European or transnational distributional conflict can be reinterpreted into a conflict between insiders and outsiders" (Dörre et al., 2016, 257). The increasing popularity, which right-wing parties encounter in parliamentary elections all over Europe has become an integral element of a new right-wing populism. In line with Dörre $(2016,261)$, this

\footnotetext{
${ }^{7}$ Additional empirical evidence for this argument was provided by Seeliger and Wagner (2018) by drawing on the de- 
development can be seen as a "movement against the impositions of the market, which have to be born by the wage-dependent and which receives the most support by the workers and the unemployed". Especially the new waves of immigration in the course of EUenlargement as well as migration in the course of the refugee crisis have - at least among parts of the working class - supported a worldview, according to which an influx of new migrant workers will only improve the economic position of the capital and bourgeoisie. This distributional conflict is gaining additional shattering power against the background of a sociocultural conflict line, Wolfgang Merkel (2016) has coined with the terms of cosmopolitarian versus communitarian positions. While cosmopolitarian positions tend to be held by persons from urban milieus with high education, communitarian positions are likely to be found among people who favor traditional relationships and cultural homogeneity. Economic globalization is from this latter perspective mostly perceived as competitive pressure (and not as an extension of the subjective opportunity structures). The increasing importance of the migration topic (Pries, 2016) symbolizes a "broad and diffuse adversity towards globalization and modern politics in general" (Nölke, 2017). The problems "arising due to a lack of political regulation of global interdependencies", concludes Geiselberger $(2017,13)$, "are affecting societies which are institutionally and culturally unprepared".

According to Hartmut Rosa $(2016 a, 289)$ the increasing popularity of right-wing populism can be interpreted as the "expression of a crisis of alienation", in the course of which more and more people get the impression that "the world is hostile towards them, and that politics do not respond to their particular needs." As the instance, which traditionally represents the interests of wage earners, the political left has - according to a number of contributions (e.g. Eribon, 2016; Baron, 2016) - been in crisis for significant time already. The success of the political right is from this perspective not least due "to the lack of understanding, lefty and alternative milieus show with regards to the new distributional conflict" (Dörre et al., 2016, 260). While the systematic infiltration of the trade unions does momentarily still constitute an opportunity for the German right-wing populist 'Alternative für Deutschland' (AfD), 'PEGIDA' or other right-wing organizations, such scenarios could become political reality not very far from today.

It can be assumed that within the current political constellation characterized by the increasing renunciation of precarious workers from the ruling political parties (Schäfer, 2016), trade unions are the organizations most likely to solve or at least mediate political conflicts in both dimensions (class politics, and culturally speaking, cosmopolitarian/communitarian). A trade union internationalism, which acts detached from its national basis runs the risk to lose its credibility in the multi-level system of international politics. Under conditions of a growing political right, Streeck $(2017,271)$ draws the following conclusions: "If you are striving for too much integration, what you'll get is conflict and less integration." A decoupled internationalism, however, is not applicable to deal with a new labor movement from the right.

\section{3 (Enlightened) institutional nationalism}

So what is to be done? In order to most effectively support policies aimed to redistribute societal wealth, trade unions should not limit their strategic repertoires in the sense of a cosmopolitarian or communitarian ideology on principle grounds. As the current discussion over the integration of the one million plus refugees in Europe shows, what the Left is lacking is not the willingness or the verve, but the concepts, categories and ideas necessary to develop an innovative position. A "crisis of leftist imagination" (Nachtwey, 2016, 232) was lately taken up by Wolfgang Merkel $(2016 a, 14)$ to proclaim necessity of a 'third way", "between cosmopolitarian generosity in giving up national sovereignty and the retreat into the communitarian refuge of the nation state". 
Instead of advocating neither international labor market regulation, nor a plain re-nationalization of economic communities, it seems promising to discuss the design of such political initiatives and solutions in greater detail. While a general closure towards migration would - under moral and functional aspects - make just as little sense as would a general opening of national labor markets (or social security systems) for everybody regardless of their nationality, capacities for political mobilization and regulation can be found on the national, as well as the international level. The political doctrine directed at the protection of national standards from cross-border downward competition can - in line with Streeck $(1995,120)$ - be described as a pattern of "institutionalized nationalism", which accepts internationalization only to a degree which does not endanger stability and autonomy of national institutions and thus does not interfere with national interests.

If in the wake of the European Court of Justice's (ECJ) jurisdiction regarding the right to strike (Bücker \& Warneck, 2010; Rödl, 2013), Scharpf (2008) for example recommends to neglect the legal obligation of national governments to follow the ECJ, this does not imply any of the right-wing demagogy, which German AfD or French Front National apply, in order to (re-)nationalize policy institutions. Neither, the strategy aims at the creation of comparative advantages. The goal is plainly the maintenance of a fundamental pillar of the German model - the right to strike.

A similar argument can be found in the discussion over the labor market integration of the refugees. While the (at least among most supporters of the left) popular demand 'Refugees Welcome' may sound appropriate under humanitarian aspects, it contains an important blind spot, when focused under class political aspects. Here, the dilemma is pretty simple: Who - under capitalism - calls for a world with no borders, automatically raises the question of how to establish a 'cartel of wage-earners'. Under current conditions, the demand for open borders (no matter if intended or not) therefore contains a neoliberal element, which the Left has so far not found an appropriate answer to. While a strategy of institutional nationalism in the sense of Streeck (1995) aims at the maintenance of national social standards, under normative aspects, the effects on public welfare have to be taken into account as well (della Porta, 2015).

Increasing competition in the low-wage segments of the labor market through the influx of refugees should, from this perspective, not be translated into a reduction of migration. Instead, the question should be posed, which economic segments and status groups are profiting from the additional wage pressure and how the economic costs and benefits could be arranged more equally among those affected. Moreover, the causes of migration and flight should be moved into the center of the debate. ${ }^{8}$ Such an enlightened institutional nationalism would then not serve the cause of the externalization (Lessenich, 2018) of economic and social cost, but the maintenance of national regulatory capacities and welfare.

\subsection{Embedded internationalism}

However, on an international level there also seems to be room for development for trade union politics. Looking back onto several decades of European Social Dialogue and limited success of interference into EU-decision-making (see e.g. Seeliger \& Wagner, 2016), it becomes apparent that the transfer of corporatist patterns from the national onto the European level has brought limited success (Schäfer \& Streeck, 2008). One opportunity for further capacity building could lie in setting the trade unions' focus onto their essential fighting instrument - the strike! Here, the introduction of European strike funds on the sectoral level could enhance especially the field of wage coordination by a power

\footnotetext{
8 Perhaps it might turn out that they are connected resource wars and exports of weaponry, from which the political
} protagonists of the institutional nationalism have been profiting in the past. 
component which the trade unions have so far been lacking to challenge European capital. If, for example, the German IG Metall would open its national strike fund to support the walkouts of their Italian, French or Slovakian colleagues, this would not only mean a material contribution to strengthen collective bargaining.

As a constitutive moment of strike activities, Boll and Kallas $(2014,536)$ - by taking the view of the participants - identify the components of collectivity (1) and excitement (2). Accordingly, by conducting a transnational strike, trade unions could support the emergence of a European consciousness on the shop floor level - the EU would suddenly become tangible. Similar approaches have on the shop floor-level (especially in the automotive industry) been pursued for quite some years under the title of 'sharing the pain'-strategies. Here, mass layoffs or other concessions were split between several plants of the company, in order to protect single subsidiaries from closing down (Pernicka et al., 2015). If therefore European Social Dialogue is bringing about little substantial outcome, if initiatives of wage coordination do not work properly either, and if the European Trade Union Confederation loses sight of the sectoral specifics in favor of an integrationist doctrine, it might be time for unions to get back down to their traditional core business of fixing a price of labor through (the threat of) strikes.

\section{Conclusion}

Attempting to carve out the macrosocial dimension of trade union politics, I have made reference to Karl Polanyi's concept of the countermovement. Polanyi's thoughts did not only serve as an analytical framework, but also as passages out of a "crisis of leftist imagination" (Nachtwey, 2016, 232). The four mobilization horizons would overlap in practice. The heuristic proposed here can, however, serve as a tool for future reflection and analysis.

With all of these potential strategies in mind, sociological research on trade unions has to consider two aspects: Firstly, trade unions' organizational structures are difficult and slow to reform. Following van der Linde $(2016,209)$ we can assume that trade unions do not even develop in line with the reformist intentions. According to him, unions' organizational apparati are "generally the outcome of conflicts and risky experiments. Pressure from below (through competitive networks and alternative action models) will be a very important factor in deciding that outcome".

Accordingly, research on labor relations in general, and trade unions in particular, will have to be conducted as a sociology of political conflict (Dörre, 2010, 912). Facing the interdependent processes of economic globalization and regional diversification of capitalist development, no particular methodological approach could generally be privileged over others. Comparative studies (Hall \& Soskice, 2001) or in-depth case studies on the epistemological basis of methodological nationalism (such as Nachtwey, 2016) should play a role here, just as genuinely trans- or supranational approaches. Additional inspiration, such a political sociology of trade unions could gain not only from organization studies (Scott \& Davis, 2006), but also through a stronger connection to theories of cohesion (Marshall, 1992), democracy (Lipset et al., 1956) and capitalism (Polanyi, 1957) in general. 


\section{References}

Altvater, E.; Mahnkopf, B. (1993). Gewerkschaften vor der europäischen Herausforderung. Tarifpolitik nach Maastricht und Mauer. Münster: Westfälisches Dampfboot.

Baccaro, L.; Howell, C. (2017). Trajectories of neoliberal transformation. European industrial relations since the 1970s. Cambridge: Cambridge University Press.

Baron, C. (2016). Proleten, Pöbel, Parasiten. Berlin: Das neue Berlin.

Beck, U. (1985). Risikogesellschaft. Auf dem Weg in eine andere Moderne. Frankfurt a.M.: Suhrkamp.

Benjamin, W. (1999). Zur Kritik der Gewalt und andere Aufsätze. Frankfurt a.M.: Suhrkamp.

Block. F.; Somers, M. R. (2014). The Power of market fundamentalism. Cambridge: Harvard University Press.

Blyth, M. (2013). Austerity. The history of a dangerous idea. Oxford: Oxford University Press.

Boll, F.; Kallass, V. (2014). Streik und Aussperrung. In Schroeder, W. (Eds.), Handbuch Gewerkschaften in Deutschland (535-580). Wiesbaden: Springer VS.

Bormann, S.; Jungehülsing, J. (2015). Einleitung: Transnationale Solidarität als Prozess denken. In Bormann, S. et al. (Eds.), Last Call for Solidarity. Perspektiven grenzüberschreitenden Handelns von Gewerkschaften (15-39). Hamburg: VSA.

Brinkmann, U.; Nachtwey, O. (2017). Postdemokratie und Industrial Citizenship. Erosionsprozesse von Demokratie und Mitbestimmung. München/Weinheim: Juventa.

Brinkmann, U.; Nachtwey, O. (2014). Prekäre Demokratie? Industrielle Beziehungen, 21, 78-98.

Brookes, M.; McCallum, J. K. (2017). The new global labour studies: A critical review. Global Labour Journal, 8(3), 201-218.

Bücker, A.; Warneck, W. (Eds.) (2010). Viking - Laval - Rüffert: Consequences and policy perspectives. Brussels: ETUI.

Burawoy, M. (2010). From Polanyi to Pollyanna: The false optimism of global. Labor Studies, 1(2), 301-313.

Castles, S. et al. (1993). The age of migration. International population movements in the modern world. New York: Guilford Press.

Child, J. et al. (1973). Towards an organizational study of trade unions. Sociology 7(1) 7191.

Clasen, J.; Viebrock, E. (2006). Das Genter System der Arbeitslosenversicherungen - immer noch gewerkschaftliches Rekrutierungsinstrument oder sozialpolitisches Auslaufmodell? Dänemark und Schweden im Vergleich. Zeitschrift für Sozialreform, 52(3), 351-371. 
Dale, G. (2015). Reconstructing Karl Polanyi: Excavation and critique. Chicago: University of Chicago Press.

Dale, G. (2017). Karl Polanyi. A life on the left. New York: Columbia University.

della Porta, D. (2015). Spreading protest: social movements in times of crisis. Colchester: ECPR Press.

Dörre, K. (2010). Überbetriebliche Regulierung von Arbeitsbeziehungen. In Böhle, F. et al. (Eds.), Handbuch Arbeitssoziologie (873-912). Wiesbaden: VS.

Dörre, K. (2016). Die national-soziale Gefahr. PEGIDA, neue Rechte und der Vertei-lungskonflikt - sechs Thesen. In Rehberg, K.-S. et al. (Eds.), PEGIDA - Rechtspopulismus zwischen Fremdenangst und "Wende"-Enttäuschung? (259-288). Bielefeld: Transcript.

Dörre, K. et al. (2016). Streikrepublik Deutschland? Die Erneuerung der Gewerkschaften in Ost und West. Frankfurt a.M./New York: Campus.

Eribon, D. (2016). Rückkehr nach Reims. Berlin: Suhrkamp.

Fairbrother, P. (2014). Unions. Practices and prospects. In Wilkinson, A. (Eds.), The Oxford Handbook of Employment Relations: Comparative Employment Systems (637-654). Oxford: Oxford University Pres.

Fraser, N. (2013). A triple movement? Parsing the politics of crisis after Polanyi, New Left Review, 81, 119-131.

Hall, P. A.; Soskice, D. (2001). Varieties of capitalism. Institutional foundations of comparative advantage. Oxford: Oxford University Press.

Geiselberger, H. (2017). Vorwort. In Id. (Ed.), Die große Regression. Eine internationale Debatte über die geistige Situation der Zeit (7-16). Berlin: Suhrkamp.

Giddens, A. (1971). Capitalism and modern social theory an analysis of the writings of Marx, Durkheim and Max Weber. Cambridge: Cambridge University Press.

Giddens, A. (1990). The consequences of modernity. Cambridge: Stanford University Press.

Goes, T. E. (2016). Aus der Krise zur Erneuerung? Gewerkschaften zwischen Sozialpartnerschaft und sozialer Bewegung. Köln: PapyRossa Verlag.

Pries, L. (2010). Erwerbsregulierung in einer globalisierten Welt. Wiesbaden: VS.

Habermas, J. (2000). The postnational constellation. Political Essays. Boston: MIT Press.

Hayek, F.v. (1994): The road to serfdom. Chicago: University of Chicago Press.

Höpner, M. (2015). Der integrationistische Fehlschluss. Leviathan, 43(1), 29-42. 
Höpner, M.; Schäfer, A. (2008). Grundzüge einer politökonomischen Perspektive auf die europäische Integration. In Ead. (Eds.), Die Politische Ökonomie der europäischen Integration (11-48). Frankfurt a.M./New York: Campus.

Hyman, R. (2013). European trade unions and the long march through the institutions. From Integration to Contention? In Fairbrother, P. (Ed.), Transnational Trade Union. Building Union Power (161-179). London: Routledge.

Kindleberger, C. P. (1974). 'The Great Transformation' by Karl Polanyi. Daedalus, 103, 4552.

Kocka, J. (2015). Arbeiterleben und Arbeiterkultur: Die Entstehung einer sozialen Klasse. Berlin: Dietz.

Krämer, R. (2015). Kapitalismus verstehen. Einführung in die Politische Ökonomie der Gegenwart. Hamburg: VSA.

Lessenich, S. (2018). Living well at others' expense. The hidden costs of western prosperity. New York: Wiley.

Lipset, S. M. et al. (1956). Union democracy: The internal politics of the international typographical union. New York: Free Press.

Loh, W.; Skupien, S. (2016). Die EU als Solidargemeinschaft Leviathan, 44(4), 578-603.

Marshall, T. H. (1992). Bürgerrechte und soziale Klassen. Zur Soziologie des Wohlfahrtsstaates. Frankfurt a.M./New York: Campus.

Matthijs, M.; Blyth, M. (Eds.) (2015). The future of the Euro. Oxford: Oxford University Press.

Merkel, W. (2016). Kosmopolitismus versus Kommunitarismus: Ein neuer Konflikt in der Demokratie. In Harfst, P. et al. (Eds.), Parties, Governments and Elites. The Comparative Study of Democracy (9-23). Wiesbaden: Springer VS.

Merkel, W. (2016a). Kosmopolitismus, Kommunitarismus und die Demokratie (WZBMitteilungen 154, 11-14).

Merton, R. K. (1968). Social theory and social structure. New York: Macmillan; Wiesbaden: VS.

Michels, R. (1911). Zur Soziologie des Parteiwesens in der modernen Demokratie. Untersuchungen über die oligarchischen Tendenzen des Gruppenlebens. Leipzig: Klinkhardt.

Nachtwey, O. (2016). Die Abstiegsgesellschaft. Über das Aufbegehren in der regressiven Moderne. Berlin: Suhrkamp.

Neumann, F. (1978). Wirtschaft, Staat, Demokratie. Aufsätze 1930-1954. Frankfurt a.M.: Suhrkamp. 
Nölke, A. (2017). Linkspopulär: Vorwärts handeln, statt rückwärts denken. Frankfurt a.M.: Westend Verlag.

Pernicka, S. et al. (2015). When does solidarity end? Transnationales Gewerkschaftshandeln in der Automobilproduktion vor und während der Krise. In Pernicka, S. (Eds.), Horizontale Europäisierung im Feld der Arbeitsbeziehungen (111-150). Wiesbaden: Springer.

Polanyi, K. (1957). The Great Transformation. Political and economic origins of our time. Boston: Beacon Press.

Polanyi, K. (1973). The Great Transformation - Politische und ökonomische Ursprünge von Gesellschaften und Wirtschaftssystemen. Frankfurt a.M.: Suhrkamp.

Pries, L. (2008). Die Transnationalisierung der sozialen Welt. Sozialräume jenseits von Gesellschaften. Frankfurt a.M.: Suhrkamp.

Pries, L. (2010). Erwerbsregulierung in einer globalisierten Welt. Wiesbaden: VS.

Pries, L. (2016). Migration und Ankommen. Die Chancen der Flüchtlingsbewegung. Frankfurt a.M./New York: Campus.

Rödl, F. (2013). Zu Begriff und Perspektiven demokratischer und sozialer Unioin. Europarecht Beiheft, 1, 179-204.

Rosa, H. (2016). Resonanz. Eine Soziologie der Weltbeziehung. Berlin: Suhrkamp.

Rosa, H. (2016). Der Versuch einer sklerotischen Gesellschaft, sich die Welt vom Leibe zu halten - und ein Vorschlag zum Neuanfang. In Rehberg, K.-S. et al. (Eds.), PEGIDA: Rechtspopulismus zwischen Fremdenangst und 'Wende-Enttäuschung? Analysen im Überblick (289-296). Bielefeld: Transcript.

Schäfer, A. (2016). Der Verlust politischer Gleichheit. Warum die sinkende Wahlbeteiligung der Demokratie schadet. Frankfurt a.M./New York: Campus.

Schäfer, A.; Streeck, W. (2008). Korporatismus in der Europäischen Union. In Höpner, M.; Schäfer, A. (Eds.), Die Politische Ökonomie der europäischen Integration (203-240). Frankfurt a.M./New York: Campus.

Scharpf, F. W. (2008). Der einzige Weg ist, dem EuGH nicht zu folgen. Interview mit Cornelia Girndt, Die Mitbestimmung 7+8/2008, 18-23.

Schulten, T.; Müller, T. (2013). Ein neuer europäischer Interventionismus? Die Auswirkungen des neuen Systems der europäischen Economic Governance auf Löhne und Tarifpolitik. Wirtschaft und Gesellschaft, 39(3), 291-320.

Scott, W. R.; Davis, G. F. (2006). Organizations and organizing: Rational, natural and open systems perspectives. Upper Saddle River: Prentice Hall.

Seccareccia, M. (2012). Critique of current neoliberalism from a Polanyian perspective. International Journal of Political Economy, 41, 3-4. 
Seeliger, M.; Wagner, I. (2016). Workers united? Political preference formation among European trade unions (Köln: Discussion Paper Reihe des Max-Planck-Institut für Gesellschaftsforschung).

Silver, B. J. (2005). Arbeiterbewegungen und Globalisierung seit 1870. Berlin: Assoziation A.

Skocpol, T. (1979). States and social revolutions. Cambridge: Cambridge University Press.

Stiglitz, R. E. (2001). Foreword. In Polanyi, Karl: The Great Transformation (VII-XI). Boston: Beacon press.

Streeck, W. (1995). Politikverflechtung und Entscheidungslücke. In Schettkat, R. et al. (Eds.), Reformfähigkeit (101-130). Frankfurt a.M./New York: Campus.

Streeck, W. (2005). The sociology of labor markets and trade unions. In Smelser, N. J.; Swedberg, R. (Eds.), The Handbook of Economic Sociology (254-283). Princeton: Princeton University Press.

Streeck, W. (2015). Gekaufte Zeit. Die vertagte Krise des demokratischen Kapitalismus. Berlin: Suhrkamp.

Streeck, W. (2015a). Labor unions. In International Encyclopedia of the Social \& Behavioral Sciences, 2nd edition, Volume 13, 8204-8210.

Streeck, W. (2016). Entkoppelt. Kapitalismus und Demokratie im neoliberalen Zeitalter. Darmstadt: bei der Fachtagung der Sektionen Politische Theorie und Ideengeschichte und Politische Ökonomie der Deutschen Vereinigung für Politische Wissenschaft.

Streeck, W. (2017). Die Wiederkehr der Verdrängten als Anfang vom Ende des neoliberalen Kapitalismus. In Geiselberger, H. (Ed.), Die große Regression. Eine internationale Debatte über die geistige Situation der Zeit (253-274). Berlin: Suhrkamp.

Streeck, W.; Schmitter, P. (1999). Gemeinschaft, Markt und Staat - und Verbände? Der mögliche Beitrag von privaten Interessenregierungen zu sozialer Ordnung. In Streeck, W. (Ed.), Korporatismus in Deutschland. Zwischen Nationalstaat und Europäischer Union (191222). Frankfurt a.M./New York: Campus.

Thompson, E. P. (1987). Die Entstehung der englischen Arbeiterklasse. Frankfurt a.M.: Suhrkamp.

Urban, H.-J. (2013). Der Tiger und seine Dompteure. Wohlfahrtsstaat und Gewerkschaften im Gegenwartskapitalismus. Hamburg: VSA.

van der Linde, Marcel (2016). Global labor: A not-so-grand ginale and perhaps a new beginning. Global Labour Journal, 7(2), 201-211.

Wagner, A.-C. (2013). The personnell of the Europen trade union confederation: Specifically European types of capital? In Georgakakis, D.; Rowell, J. (Eds.), The Field of Eurocracy: Mapping EU Actors and Professionals (188-201). New York: Palgrave Macmillan. 
Wagner, I.; Lillie, N. (2014). European integration and the disembedding of labour market regulation: Transnational Labour Relations at the European Central Bank Construction Site. In: Journal of Common Market Studies 52(2), 403-419.

Walby, S. (2009). Globalization and inequalities. Complexity and contested modernities. London: SAGE.

Webb, B.; Webb, S. (1895). Die Geschichte des Britischen Trade Unionismus. Stuttgart: Dietz Verlag.

Webster, E. (1985). Cast in a racial mould. Labour process and trade unionism in the foundries. Johannesburg: Ravan Press.

Webster, E. et al. (2009). Grounding globalization. Labour in the age of insecurity. London: Blackwell.

Wissel, J. (2015). Staatsprojekt EUropa: Grundzüge einer materialistischen Theorie der Europäischen Union. Münster: Westfälisches Dampfboot. 